\title{
The Fluxes of Organic $C$ and $N$, and Microbial Biomass and Maize Yield in an Organically Manured Ultisol of the Guinea Savanna Agroecological Zone of Nigeria
}

\author{
S. O. Agele, S. O. Ojeniyi, S. K. Ogundare \\ Department of Crop, Soil \& Pest Management, Federal University of Technology, Akure, Nigeria \\ Email: ohiagele@yahoo.com
}

Received 18 May 2015; accepted 14 October 2015; published 19 October 2015

Copyright @ 2015 by authors and Scientific Research Publishing Inc.

This work is licensed under the Creative Commons Attribution International License (CC BY). http://creativecommons.org/licenses/by/4.0/

c) (i) Open Access

\section{Abstract}

Field experiments were conducted to evaluate the effects of integrated use of agricultural wastes and a compound mineral fertilizer on the fluxes of soil nutrients. Agricultural wastes applied were: livestock manure (cow dung and poultry litter), shoots of Chromolaena odorata and Parkia biglosa (locust bean), Neem (Azadiracta inidca) seed powder/cake and melon shell. These materials were applied at zero (control), $100 \%$ (i.e. organic wastes applied at the recommended rates of $10 \mathrm{t} / \mathrm{ha}$ ) and $70 \%$ of their recommended rates plus $30 \%$ of the recommended rate of the mineral fertilizer (NPK: $400 \mathrm{Kg} / \mathrm{ha}$ ). Average values of soil organic carbon (SOC) were 1.94, 1.68, 1.36 and 1.38 for organic wastes alone, organic waste plus mineral fertilizer (NPK) and unamended control. Mineral $\mathrm{N}\left(\mathrm{NO}_{3}^{-} \mathrm{N}\right.$ plus $\left.\mathrm{NH}_{4}^{+} \mathrm{N}\right)$ pools were relatively high at 30 and 60 days after planting, and were significantly higher for organically amended soils (550) and wastes applied at reduced rates combined with $120 \mathrm{~kg} / \mathrm{ha}$ mineral NPK (470) than the unamended control (277). Across sampling dates, SOC values were the highest in poultry manure and neem seed cake. The values of $\mathrm{NO}_{3}^{-} \mathrm{N}$ plus exchangeable $\mathrm{NH}_{4}^{+} \mathrm{N}$ which constitutes plant available nitrogen (PAN) were significantly higher for organically amended soils and wastes applied at reduced rates combined with 120 $\mathrm{kg} / \mathrm{ha}$ mineral NPK than the unamended control. The \% $\mathrm{C}$ microbial to $\mathrm{C}$ organic ratio was higher in organically amended soils. The temporal profile of $\mathrm{SOC}, \mathrm{NH}_{4}-\mathrm{N}$ and $\mathrm{NO}_{3}-\mathrm{N}$ showed declines with time, the relationship was linear for $\operatorname{SOC}\left(Y=0.18 \mathrm{x}+1.07 ; R^{2}=0.34\right)$, by a power function for $\mathrm{NO}_{3}^{-} \mathrm{N}\left(\mathrm{Y}=48.084 \mathrm{x}^{-1.79} ; \mathrm{R}^{2}=0.91\right)$ and a polynomial function for $\mathrm{NH}_{4}-\mathrm{N}(\mathrm{Y}=-28.75 \mathrm{x}+130.65 \mathrm{x}-$ $57.25 ; R^{2}=0.61$ ). The time dynamics of microbial population (cfu) followed trends obtained for SOC. 


\section{Keywords}

Organic, Carbon, Mineral N, Microbial Biomass, Savanna, Ultisol, Tropics

\section{Introduction}

In Nigeria, the vegetation zones and the agroecologies vary from the humid tropical rainforest to the savanna. However, soils of the Southern Guinea Savanna zones are inherently low in nitrogen and organic matter and crop yields on these soils are low [1]. In this zone, there is widespread use of both organic and inorganic fertilizers to improve soil and crop productivity. The merits of organic over inorganic fertilizers include better crop establishment and improved efficiency of utilization of the applied materials [2]. Organic manure improves physical properties of soils and replenishes depleted soil organic matter. However, the use of organic manure is faced with limitations such as slow decomposition and mineralization rates, bulkiness, dirt, etc. Integrated use of inorganic and organic fertilizer is therefore required for sustainable soil and crop productivity.

Due to the problems associated with the use of inorganic fertilizers, combine use of organic and inorganic manures may be beneficial to soil and crop productivity in this agroecology. A balanced use of organic and mineral fertilizer could enhance soil chemical, physical and biological properties in addition to rapid rate of nutrient turnover within the soil-plant system. Integrated use of organic wastes and mineral fertilizer is reported to reduce the cost and amount of fertilizer required by crops [3]-[5]. Bair [6] opined that proper soil fertility management and sustainable agriculture could be achieved with the use of both mineral fertilizer and organic manure. Paul and Mannan [7] suggested that integrated nutrient management through combined use of organic wastes and chemical fertilizers could be an effective approach to combat nutrient depletion and promote sustainable crop productivity. Replenishing the nutrients removed by crops by recycling agricultural wastes into the soil could sustain soil and crop productivity [7]. Practices which focus on recycling agricultural wastes into the soil would contribute to improved quality and health of the soil.

There is dearth of information on effect in integrated application of agricultural wastes and mineral fertilizer on soil physical and chemical properties in a Southern Guinea Savanna zone of Nigeria, an agroecological zone that is characterised by inherently low soil fertility status and rapid nutrient depletion especially organic matter depletion. However, the Southern Guinea Savanna is also characterized by abundant agricultural land and high potential for crop production; however, soils of this agroecology are characterized by inherently low in soil fertility and rapid nutrient depletion and other forms of soil degradation. Tropical soils under different soil nutrient management practices have a wide range of mineralization potentials inadequate information on $\mathrm{C}$ and $\mathrm{N}$ fluxes in these soils. Understanding the carbon (C) and nitrogen (N) dynamics in the soil-plant system is essential to successful soil nutrient management. In addition, understanding the chemical and biological processes of fluxes of carbon and nitrogen in organically amended soils would help to fine tune nutrient management strategies, improve crop nutrient use efficiency and the quality of the environment.

The role of microbial immobilisation, clay fixation, denitrification and ammonia volatilisation in determining soil mineral $\mathrm{N}$ dynamics following organic amendment has been reported. For example, [8] and [9] reported that after manure addition to soil, a decrease of soil mineral $\mathrm{N}$ as observed in the short term in the manured compared to the unmanured control treatment, probably due to microbial immobilization. Moreover, studies conducted using ${ }^{15} \mathrm{~N}$ suggest that part of this immobilized $\mathrm{N}$ is stored in the soil in organic form, at least for a few years after manure addition [10]. The process of organic matter accumulation as a result of repeated manure applications has been studied from field experiments [11] [12]. The study designed to assess the fate of added $\mathrm{N}$ in different compartments is affected by the confounding effect of other inputs or outputs [8] [9] [13]. Laboratory experiments permit the measurement of the net $\mathrm{N}$ mineralisation of manures, thus reducing the confounding effects of other inputs or outputs. However, under field conditions the fluxes of soil $\mathrm{N}$ in different compartments are due to the contemporary processes of crop $\mathrm{N}$ uptake, $\mathrm{N}$ loss, and mineralisation of native and added organic matter.

Soil $\mathrm{N}$ dynamics is characterized by a series of transformation processes between organic and inorganic forms of $\mathrm{N}$. Soil $\mathrm{N}$ pool is affected by inorganic $\mathrm{N}$ which is derivable from mineralization process, $\mathrm{N}$ addition via fertilizer usage and soil $\mathrm{N}$ losses via leaching or volatilization, $\mathrm{N}$ removal by crops and/or addition of $\mathrm{N}$ fertilizer 
materials to soil, microbial immobilization/fixation. Accurate estimation of the capacity of the soil to mineralize organic nitrogen is important. Nitrogen is the key element to plant production and modern farming systems require an ample supply of $\mathrm{N}$ fertilizer necessary for maximum crop yield. The relationship between total $\mathrm{N}$ and mineralized $\mathrm{N}$ has been widely studied [7] [11]. Soil or native ammonium fixation is involved in the $\mathrm{N}$ dynamics of soil and may be an important component of the $\mathrm{N}$ fertility status of some agricultural soils [9].

Carbon to nitrogen ratio is an indicator of the decomposing ability of soil organic matter and consequently of the $\mathrm{N}$ supplying potential of the soil [8]. Organic (agricultural) wastes have the potential to slow down nitrification process possibly via slow hydrolysis of the mineral fertilizer (reduced nitrification rate of urea). Patra et al. [14] reported that agricultural wastes had the potential to inhibit urease activity and slow down the release of $\mathrm{NH}_{4}-\mathrm{N}$ into the soil. Application of organic wastes to agricultural soils not only contributes to the short term fertility but also determines the residual pool of nutrients in the soil. It is not clear how different manure types (due to the different rates of decomposition of the organic fraction) and different soils (due to different clay content) may impact on microbial turnover and clay fixation in soil such as the Ultisols of the humid tropics. A detailed analysis of $\mathrm{C}$ and $\mathrm{N}$ sinks from organically amended tropical soils Ultisols in particular has yet to be undertaken. Tropical soils have a wide range of inadequate information of mineralization potentials on $\mathrm{C}$ and $\mathrm{N}$ fluxes in these soils, and adequate understanding of the chemical and biological processes of fluxes of carbon and nitrogen from tropical soils is required. Ultisols occupy a great part of the soils resources in Nigeria and information on $\mathrm{C}$ and $\mathrm{N}$ fluxes in these soils is inadequate.

This study examines the effects of integrated management of some agricultural waste materials and mineral fertilizer (commercially available compound fertilizer containing N-P-K) on the fluxes of soil nutrients (soil organic carbon, microbial biomass $\mathrm{C}$ and $\mathrm{N}$, and forms of plant available soil $\mathrm{N}\left(\mathrm{NO}_{2}-\mathrm{N}+\mathrm{NO}_{3}-\mathrm{N}_{\text {and }} \mathrm{NH}_{4}-\mathrm{N}\right)$ and microbial biomass- $\mathrm{C}$ and $\mathrm{N}$ of an Ultisol in a humid savanna agroecological zone of Nigeria.

\section{Materials and Methods}

Field experiments were conducted at the Lower Niger River Basin Development Authority (L.N.R.B.D.A) farm located in Isanlu, Kogi State of the Southern Guinea Savanna zone of Nigeria in 2008 and 2009 cropping seasons.

\subsection{Treatments}

Treatments consisted of sole and combined application of a compound mineral fertilizer (N-P-K, 15-15-15) and agricultural waste materials (cow dung and poultry litter, shoots of Chromolaena odorata and Parkia biglosa (locust bean), neem (Azadiracta inidca) seed cake and melon shell). The mineral fertilizer and agricultural wastes were separately applied at their recommended rates of $400 \mathrm{~kg} / \mathrm{ha}$ and $10 \mathrm{t} / \mathrm{ha}$ [12] while integrated use of NPK and wastes consisted of application of $30 \%$ and $70 \%$ of their recommended rates $(120 \mathrm{~kg} / \mathrm{ha} \mathrm{NPK}+7 \mathrm{t} / \mathrm{ha}$ of waste). There was an unmanured control.

The mineral fertilizer (N-P-K, 15 - 15 - 15) and agricultural wastes were split applied. The organic materials were applied a week before planting and NPK at planting while the second application was at 6 weeks after planting (WAP).Weeding was carried out manually at 3 and 8 WAP.

\subsubsection{Chemical Analysis of Agricultural Waste Materials}

Samples of the agricultural wastes were taken for chemical (C: N ratio, organic carbon, N, P, K, Ca and Mg) analyses and results are presented in Table 1.

\subsubsection{Soil Sampling and Analysis}

Before the commencement of the experiment, surface soil samples (0 - $15 \mathrm{~cm}$ depth) were taken randomly from the field plots and at crop maturity. The samples were bulked, air dried and sieved using 2 mm sieve and they were subjected to routine physical (particle size, bulk density, soil moisture and temperature regimes) and chemical (pH, organic matter, N, P, K, Ca Mg and CEC) analyses in the laboratory. The results are presented in Table 2. At 30, 60 and 90 days after manure application, surface soil samples were collected from treatment plots for chemical analyses. The mineral (plant available $\mathrm{N}$; $\mathrm{NH} 4-\mathrm{N}$ and $\mathrm{NO}_{3}-\mathrm{N}$ ) forms of $\mathrm{N}$ were extracted with $100 \mathrm{~mL} 1 \mathrm{M} \mathrm{KCl}$ from $30 \mathrm{~g}$ of soil. Suspensions were shaken for $1 \mathrm{~h}$ and then filtered through Whatman 40 filter paper. Concentrations of $\mathrm{NH}_{4}-\mathrm{N}$ and $\mathrm{NO}_{3}-\mathrm{N}$ of the $\mathrm{KCl}$ extracts were determined by flow injection analy- 
Table 1. Chemical composition of agricultural waste materials used for the experiments.

\begin{tabular}{cccccccc}
\hline Chemical parameters & $\begin{array}{c}\text { Poultry } \\
\text { manure }\end{array}$ & $\begin{array}{c}\text { Cow } \\
\text { dung }\end{array}$ & $\begin{array}{c}\text { Chromoleana } \\
\text { shoot }\end{array}$ & Parkia leaves & $\begin{array}{c}\text { Neem } \\
\text { seed cake }\end{array}$ & Mellon shell & $\begin{array}{c}\text { LSD } \\
(0.05)\end{array}$ \\
\hline Organic carbon (\%) & 38.4 & 43.4 & 51.9 & 54.0 & 54.2 & 56.1 & 4.3 \\
Total N (\%) & 3.6 & 2.8 & 4.2 & 3.1 & 2.1 & 1.9 & 0.7 \\
C: N & 10.7 & 15.9 & 12.6 & 17.7 & 25.5 & 28.3 & 4.2 \\
Phosphorous (\%) & 1.3 & 1.1 & 1.3 & 1.0 & 1.3 & 0.6 & 0.4 \\
Potassium (\%) & 3.1 & 0.8 & 1.5 & 2.1 & 1.9 & 0.5 & 0.6 \\
Calcium (\%) & 1.2 & 1.2 & 1.1 & 1.0 & 1.0 & 0.6 & 0.4 \\
Magnesium (\%) & 0.3 & 0.2 & 0.7 & 0.2 & 0.1 & 0.4 & 0.3 \\
\hline
\end{tabular}

Table 2. Physical and chemical properties of soil $(0-15 \mathrm{~cm})$ before the experiment.

\begin{tabular}{|c|c|c|c|}
\hline Properties & 2008 & 2009 & Mean \\
\hline Sand (\%) & 54.8 & 60.4 & 57.6 \\
\hline Clay (\%) & 27.2 & 24.0 & 25.2 \\
\hline Silt (\%) & 18.0 & 15.6 & 16.8 \\
\hline Soil texture & sandy clay loam & sandy clay loam & \\
\hline $\mathrm{pH}\left(\mathrm{H}_{2} \mathrm{O}\right)$ & 5.9 & 5.5 & 5.7 \\
\hline Bulk density $\left(\mathrm{g} \cdot \mathrm{cm}^{-3}\right)$ & 1.31 & 1.47 & 1.39 \\
\hline Total porosity (\%) & 41.1 & 43.3 & 42.2 \\
\hline Organic matter (\%) & 1.93 & 1.83 & 1.88 \\
\hline Total N (\%) & 0.18 & 0.09 & 0.14 \\
\hline Available p (mg·kg $\left.{ }^{-1}\right)$ & 2.34 & 2.74 & 2.54 \\
\hline Exchangeable K (c·mol $\left.\cdot \mathrm{kg}^{-1}\right)$ & 0.22 & 0.16 & 0.19 \\
\hline Exchangeable Ca (c·mol $\left.\cdot \mathrm{kg}^{-1}\right)$ & 2.60 & 1.91 & 2.26 \\
\hline Exchangeable $\mathrm{Mg}\left(\mathrm{c} \cdot \mathrm{mol} \cdot \mathrm{kg}^{-1}\right)$ & 3.39 & 1.80 & 2.60 \\
\hline
\end{tabular}

sis and spectrometric detection (FIAstar 5000 Analyzer, Foss Tecator, Denmark). Analysis of $\mathrm{NH}_{4}-\mathrm{N}$ was by the gas semi-permeable membrane method according to the ISO 11,732 procedure. Analysis of $\mathrm{NO}_{3}-\mathrm{N}$ was by the sulphanilamide-naphtylethylendiamine dihydrocloride method, after preliminary reduction of $\mathrm{NO}_{3}$ to $\mathrm{NO}_{2}$ by a copper-cadmium reductor column. Thereafter, soil total $\mathrm{N}$ and inorganic $\mathrm{N}$ was determined while plant available $\mathrm{N}$ (PAN) was calculated as the soil mineral nitrogen (SMN) in the manured treatments minus the SMN in the unmanured control. PAN was expressed as a fraction of added manure $\mathrm{N}$.

\subsubsection{Statistical Analysis}

Data collected from each year experiment were subjected to analysis of variance (ANOVA) test SPSS statistical package. Treatment means were compared using the Least Significant Difference (LSD) test at $(\mathrm{P}=0.05)$.

\section{Results}

\subsection{Trends of Soil Organic Carbon, Microbial Biomass and Plant Available Soil N}

The dynamics of soil organic carbon, microbial biomass $\mathrm{C}$ and $\mathrm{N}$, and forms of plant available soil $\mathrm{N}\left(\mathrm{NO}_{2}-\mathrm{N}+\right.$ $\mathrm{NO}_{3}-\mathrm{N}$ and $\mathrm{NH}_{4}-\mathrm{N}$ and microbial biomass-C and $\mathrm{N}$ were monitored following organic amendment of an Ultisol using agricultural wastes: Farm yard manure (cow dung and poultry litter), shoots of Chromolaena odorata and Parkia biglosa (locust bean), neem (Azadiracta inidca) seed powder/cake and melon shell.

Although the trend of the effects of wastes application on microbial population were inconsistent however, temporal trends in microbial population follows time changes in soil organic carbon (SOC) (Table 3). The highest values were obtained for poultry manure, Parkia and Neem seed cake while combined application of 
Table 3. Trends in soil microbial population as affected by application of agricultural wastes and a compound mineral fertilizer.

\begin{tabular}{cccccccccc}
\hline Treatments & \multicolumn{3}{c}{ Fungi sfu/g $\times 10^{3}$} & \multicolumn{3}{c}{ Bacteria (sfu/g $\left.\times 10^{3}\right)$} & \multicolumn{3}{c}{ Organic matter (g/g) } \\
\hline & 30 & 60 & 90 & 30 & 60 & 90 & 30 & 60 & 90 \\
\hline NPK & 93 & 130 & 67 & 293 & 280 & 245 & 1.24 & 1.64 & 1.62 \\
Chr & 95 & 65 & 85 & 420 & 324 & 254 & 1.25 & 1.55 & 1.50 \\
Chr + NPK & 89 & 130 & 128 & 266 & 270 & 223 & 0.83 & 1.12 & 1.06 \\
Nm & 93 & 110 & 95 & 296 & 340 & 271 & 1.42 & 1.71 & 1.67 \\
Nm + NPK & 80 & 92 & 110 & 310 & 353 & 231 & 1.26 & 1.56 & 1.48 \\
Pak & 64 & 77 & 85 & 384 & 386 & 265 & 1.20 & 1.23 & 1.20 \\
Pak + NPK & 97 & 110 & 103 & 412 & 389 & 224 & 0.94 & 1.03 & 0.98 \\
CwD & 73 & 63 & 83 & 327 & 365 & 271 & 1.06 & 1.30 & 1.16 \\
CwD + PK & 78 & 85 & 86 & 338 & 320 & 237 & 1.21 & 1.28 & 1.88 \\
Ptr & 81 & 90 & 94 & 384 & 412 & 285 & 1.27 & 2.51 & 1.71 \\
Ptr + NPK & 93 & 100 & 96 & 343 & 361 & 256 & 1.18 & 2.43 & 2.05 \\
Mel & 95 & 113 & 98 & 302 & 344 & 277 & 1.44 & 1.75 & 1.70 \\
Mel + NPK & 82 & 95 & 114 & 313 & 356 & 234 & 1.26 & 1.56 & 1.48 \\
Ctrl & 78 & 61 & 88 & 301 & 345 & 286 & 0.87 & 0.96 & 0.89 \\
SE (27 df) & 2.7 & 3.6 & 3.8 & 8.9 & 11.3 & 3.5 & 0.07 & 0.4 & 0.08 \\
LSD (0.05) & 3.62 & 4.84 & 5.09 & 12.19 & 15.48 & 6.85 & 0.11 & 0.55 & 0.11 \\
\hline
\end{tabular}

NPK alone; Chromolaena alone (Chr); Chromolaena + Urea (Chr + NPK); Neem seed powder alone (Nm), Neem + NPK (Nm + NPK), Parkia leaves alone (Pak), Parkia leaves + NPK Pak + NPK), Cowdung alone (CwD), Cowdung + NPK (CwD + NPK), Poultry manure alone (Ptr), Poultry manure + NPK (Ptr + NPK), Melon shell powder (Mel), Melon shell powder + NPK (Mel + NPK), Unmanured control (Ctrl).

wastes and NPK depressed microbial population. The \% C microbial to C organic ratio was stable for all treatments, its magnitude was not similar among treatments, higher values were obtained from organically amended soils (Table 4). The ratios of \% C microbial to \% C organic were higher in the nutrient-rich organically amended soils which indicated that increased $\mathrm{N}$ mineralisation were facilitated by higher amounts of SOC. Organic amendment alone and in combination with mineral fertilizer (NPK) produced changes in soil chemical

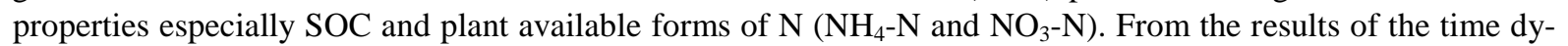
namics in SOC pools, differences were obtained at the various dates of sampling (Table 4). Highest values of SOC were obtained at 30 and 60 days after planting (DAP), these values declined subsequently after. For example, across the sampling dates, the values of SOC were highest in poultry manure and neem seed cake, the average values of SOC were 1.94, 1.68, 1.36 and 1.38 for organic wastes alone, organic waste plus mineral fertilizer (NPK), mineral fertilizer and unamended control respectively (Table 4).

The temporal trends of soil contents of $\mathrm{NO}_{3}-\mathrm{N}$ and $\mathrm{NO}_{4}-\mathrm{N}$ are presented in Table 5. Differences were also obtained for inorganic $\mathrm{N}$ pool in the soil at the various dates of sampling. The results show that the contents in the soil $\mathrm{NO}_{3}-\mathrm{N}$ decreased with time. The values of soil $\mathrm{NO}_{3}-\mathrm{N}$ were highest at 20 and lowest at 120 days after planting. Sole application of NPK fertilizer produced the highest released of $\mathrm{NO}_{3}-\mathrm{N}$, which was closely followed by combined application of agricultural wastes and NPK. The unamended control and plots amended with agricultural wastes had highest valves of $\mathrm{NO}_{3}-\mathrm{N}$ at 20 days after planting. However, at 40 days, sole application of agricultural wastes released $\mathrm{NO}_{3}-\mathrm{N}$ more than unamended control, this pattern was followed up to 120 days. Similar to the observation for soil $\mathrm{NO}_{3}-\mathrm{N}$, the temporal trends of soil $\mathrm{NO}_{4}-\mathrm{N}$ also show that values increased from 20 to 40 DAP, followed by declining trends afterwards, considerably low values were obtained at 120 DAP (Table 5). At 20 days after planting, sole application of NPK produced highest available soil $\mathrm{NH}_{4}-\mathrm{N}$, followed by application of agricultural wastes plus reduced level of NPK. About 40 days after planting appeared to be pe- 
Table 4. Dynamics of microbial biomass- $\mathrm{C}$ and $\mathrm{N}$ as affected by application of agricultural wastes and a compound mineral fertilizer.

\begin{tabular}{ccccccccccccc}
\hline Treatments & \multicolumn{3}{c}{$\begin{array}{c}\text { Organic carbon } \\
(\mathrm{mg} / \mathrm{g})\end{array}$} & \multicolumn{3}{c}{$\begin{array}{c}\text { Microbial } \\
\text { biomass-C }(\mu \mathrm{g} / \mathrm{g})\end{array}$} & $\begin{array}{c}\text { Microbial biomass-N } \\
(\mu \mathrm{g} / \mathrm{g})\end{array}$ & \multicolumn{3}{c}{$\begin{array}{c}\text { Ratio of organic carbon to } \\
\text { microbial biomass-C }\left(\times 10^{3}\right)\end{array}$} \\
\hline & 30 & 60 & 90 & 30 & 60 & 90 & 30 & 60 & 90 & 30 & 60 & 90 \\
\hline NPK & 1.24 & 1.64 & 1.62 & 611 & 456 & 372 & 79 & 63 & 50 & 2.03 & 3.60 & 4.35 \\
Chr & 1.25 & 1.55 & 1.50 & 423 & 305 & 241 & 71 & 60 & 46 & 2.96 & 5.08 & 6.22 \\
Chr+ NPK & 0.83 & 1.12 & 1.06 & 607 & 412 & 358 & 83 & 68 & 52 & 1.37 & 2.72 & 2.96 \\
Neem & 1.42 & 1.71 & 1.67 & 653 & 423 & 366 & 84 & 70 & 55 & 2.17 & 4.04 & 4.56 \\
Neem + NPK & 1.26 & 1.56 & 1.48 & 515 & 285 & 231 & 70 & 56 & 41 & 2.45 & 5.47 & 4.41 \\
Pak & 1.20 & 1.23 & 1.20 & 615 & 405 & 361 & 86 & 72 & 56 & 1.95 & 3.04 & 3.32 \\
Pak + NPK & 0.94 & 1.03 & 0.98 & 511 & 296 & 237 & 72 & 58 & 42 & 1.84 & 3.48 & 4.14 \\
Cow Dung & 1.06 & 1.30 & 1.16 & 631 & 408 & 417 & 82 & 70 & 54 & 1.68 & 3.19 & 2.78 \\
CwD + NPK & 1.21 & 1.28 & 1.24 & 508 & 283 & 234 & 68 & 56 & 38 & 2.38 & 4.52 & 5.30 \\
Ptr & 1.27 & 2.51 & 2.07 & 847 & 678 & 293 & 71 & 59 & 44 & 1.50 & 3.70 & 7.06 \\
Ptr + NPK & 1.18 & 2.43 & 2.05 & 733 & 471 & 344 & 88 & 75 & 60 & 1.61 & 5.16 & 5.96 \\
Melon & 1.44 & 1.75 & 1.70 & 656 & 427 & 369 & 87 & 73 & 57 & 2.19 & 4.10 & 4.61 \\
Melon + NPK & 1.26 & 1.56 & 1.48 & 511 & 277 & 226 & 68 & 55 & 48 & 2.47 & 5.63 & 6.55 \\
Ctrl & 0.87 & 0.96 & 0.89 & 417 & 372 & 279 & 64 & 52 & 36 & 2.09 & 2.58 & 3.19 \\
SE (27 df) & 0.15 & 0.03 & 0.02 & 1.4 & 15.8 & 8.9 & 3.9 & 4.7 & 3.5 & 0.17 & 0.55 & 0.75 \\
LSD (0.05) & 0.21 & 0.04 & 0.03 & 1.92 & 21.7 & 12.2 & 5.3 & 6.5 & 4.8 & 0.23 & 0.78 & 1.03 \\
\hline
\end{tabular}

NPK alone; Chromolaena alone (Chr); Chromolaena + Urea (Chr + NPK); Neem seed powder alone (Nm), Neem + NPK (Nm + NPK), Parkia leaves alone (Pak), Parkia leaves + NPK Pak + NPK), Cowdung alone (CwD), Cowdung + NPK (CwD + NPK), Poultry manure alone (Ptr), Poultry manure + NPK (Ptr + NPK), Melon shell powder (Mel), Melon shell powder + NPK (Mel + NPK), Unmanured control (Ctrl).

Table 5. Dynamics of mineral $\mathrm{N}$ as affected by application of agricultural wastes and a compound mineral fertilizer.

\begin{tabular}{cccccccccccc}
\hline Treatments & \multicolumn{3}{c}{$\mathrm{NH}_{4}-\mathrm{N}(\mu \mathrm{g} / \mathrm{g})$} & \multicolumn{5}{c}{$\mathrm{NO}_{3}-\mathrm{N}_{\left(\mathrm{NO}_{2}+\mathrm{NO}_{3}\right)(\mu \mathrm{g} / \mathrm{g})}$} \\
\hline NPK & 0 & 30 & 60 & 90 & 120 & 0 & 30 & 60 & 90 & 120 \\
Chr & 62 & 370 & 191 & 86 & 17 & 47 & 36 & 18 & 8 & 2.4 \\
Chr+ NPK & 43 & 331 & 157 & 53 & 5 & 36 & 28 & 11 & 4 & 1.2 \\
Nm & 54 & 363 & 173 & 71 & 11 & 42 & 32 & 15 & 5 & 1.5 \\
Nm + NPK & 40 & 326 & 154 & 54 & 6 & 34 & 26 & 10 & 4 & 1.3 \\
Pak & 52 & 347 & 168 & 63 & 10 & 41 & 33 & 13 & 5 & 1.6 \\
Pak+ NPK & 37 & 322 & 152 & 48 & 5 & 35 & 25 & 9 & 3.4 & 1.1 \\
Cow dung & 50 & 341 & 164 & 62 & 9 & 40 & 30 & 12 & 4 & 1.5 \\
CwD + NPK & 35 & 328 & 147 & 50 & 6 & 30 & 22 & 8 & 3.2 & 1.2 \\
Ptr & 48 & 350 & 160 & 61 & 10 & 38 & 28 & 13 & 4 & 1.5 \\
Ptr + NPK & 37 & 334 & 148 & 54 & 7 & 35 & 25 & 8 & 3.1 & 1.0 \\
Melon shell & 52 & 358 & 163 & 68 & 12 & 40 & 33 & 14 & 5 & 2.0 \\
Mel + NPK & 42 & 329 & 152 & 51 & 8 & 31 & 28 & 12 & 5 & 1.5 \\
Control & 54 & 344 & 171 & 61 & 12 & 44 & 32 & 15 & 6 & 1.8 \\
SE (27 df) & 31 & 293 & 130 & 47 & 4 & 31 & 22 & 6 & 2.4 & 0.8 \\
LSD (0.05) & 3.4 & 5.7 & 6.2 & 5.2 & 1.8 & 3.4 & 2.2 & 1.7 & 0.9 & 0.3 \\
\hline
\end{tabular}

NPK alone; Chromolaena alone (Chr); Chromolaena + Urea (Chr + NPK); Neem seed powder alone (Nm), Neem + NPK (Nm + NPK) ,Parkia leaves alone (Pak), Parkia leaves + NPK Pak + NPK), Cowdung alone (CwD), Cowdung + NPK (CwD + NPK), Poultry manure alone (Ptr), Poultry manure + NPK (Ptr + NPK), Melon shell powder (Mel), Melon shell powder + NPK (Mel + NPK), Unmanured control (Ctrl). 
riod of peak of $\mathrm{NH}_{4}-\mathrm{N}$ availability; The combined application of waste and NPK released the highest $\mathrm{NH}_{4}-\mathrm{N}$, followed by sole agricultural wastes and sole NPK fertilizer, un amended control recorded the least value of soil $\mathrm{NH}_{4}-\mathrm{N}$. The pattern was consistent at both 80 and 120 days after planting. In general, the average values of SOC, $\mathrm{NH}_{4}^{+}$and $\mathrm{NO}_{3}^{-}$turnover rates were comparatively greater $(1.94 ; 19 ; 119)$ in the organic amended than the unamended (1.36; 15.5; 54) soils (Table 4 and Table 5). $\mathrm{Soil}_{\mathrm{NO}_{3}}{ }^{-\mathrm{N}}$ plus exchangeable $\mathrm{NH}_{4}{ }^{+} \mathrm{N}$ constitutes plant available nitrogen (PAN) that was recovered. PAN were significantly higher for organically amended soils and wastes applied at reduced rates combined with $120 \mathrm{~kg} / \mathrm{ha}$ mineral NPK than the unamended control.

\subsection{Time dynamics of soil organic carbon and soil $\mathrm{NO}_{3}-\mathrm{N}$ and $\mathrm{NH}_{4}-\mathrm{N}$}

The time changes in SOC contents are shown in Figure 1. Declining SOC with time was obtained and the declining in the status of SOC is linearly related with time $\left(\mathrm{Y}=0.18 \mathrm{x}+1.07 ; \mathrm{R}^{2}=0.34\right)$, Positive changes were obtained at 40 and 80 DAP and declines in SOC beyond 80 DAP. The time changes in soil $\mathrm{NO}_{3}-\mathrm{N}$ contents is presented in Figure 2. The result showed that there were negative changes in soil $\mathrm{NO}_{3}-\mathrm{N}$ with time. The nature of the decline in NO3-N is related with time by a power function $\left(\mathrm{Y}=48.084 \mathrm{x}^{-1.79} ; \mathrm{R}^{2}=0.91\right)$. Sharp decline in soil $\mathrm{NO}_{3}-\mathrm{N}$ and $\mathrm{NH}_{4}-\mathrm{N}$ contents with time under organic amendment alone and the control was obtained (Figure 2 and Figure 3). Increasing trend in $\mathrm{NH}_{4}-\mathrm{N}$ contents in the soil was found between 20 and 40 DAP followed by declining NH4-N contents from 40 to 120 DAP (Figure 3). The inhibition of nitrification greater in organic waste application combined with mineral fertilizer (NPK). The nature of the decline in NH4-N is related with time by a polynomial function $\left(\mathrm{Y}=-28.75 \mathrm{x}+130.65 \mathrm{x}-57.25 ; \mathrm{R}^{2}=0.61\right)$. The lowest values of $\mathrm{NH}_{4}-\mathrm{N}$ obtained from the applied fertilizer were observed from soil samples at 120 days after treatment application. The soil organic matter (SOM) content increased after two years of cultivation irrespective of the organic wastes applied (Table 6). Application of organic wastes plus mineral fertilizer (NPK) increased SOM over sole application of wastes. In soil amended with poultry manure, highest SOM values were recorded, the control plots showed slight increases (17\%) in SOM at the end of the two year experiment. The trends of increases in SOM stocks were poultry manure, cow dung, Chromolaena and Parkia shoots, and neem seed cake applied in addition to $120 \mathrm{~kg} / \mathrm{ha}$ NPK mineral fertilizer.

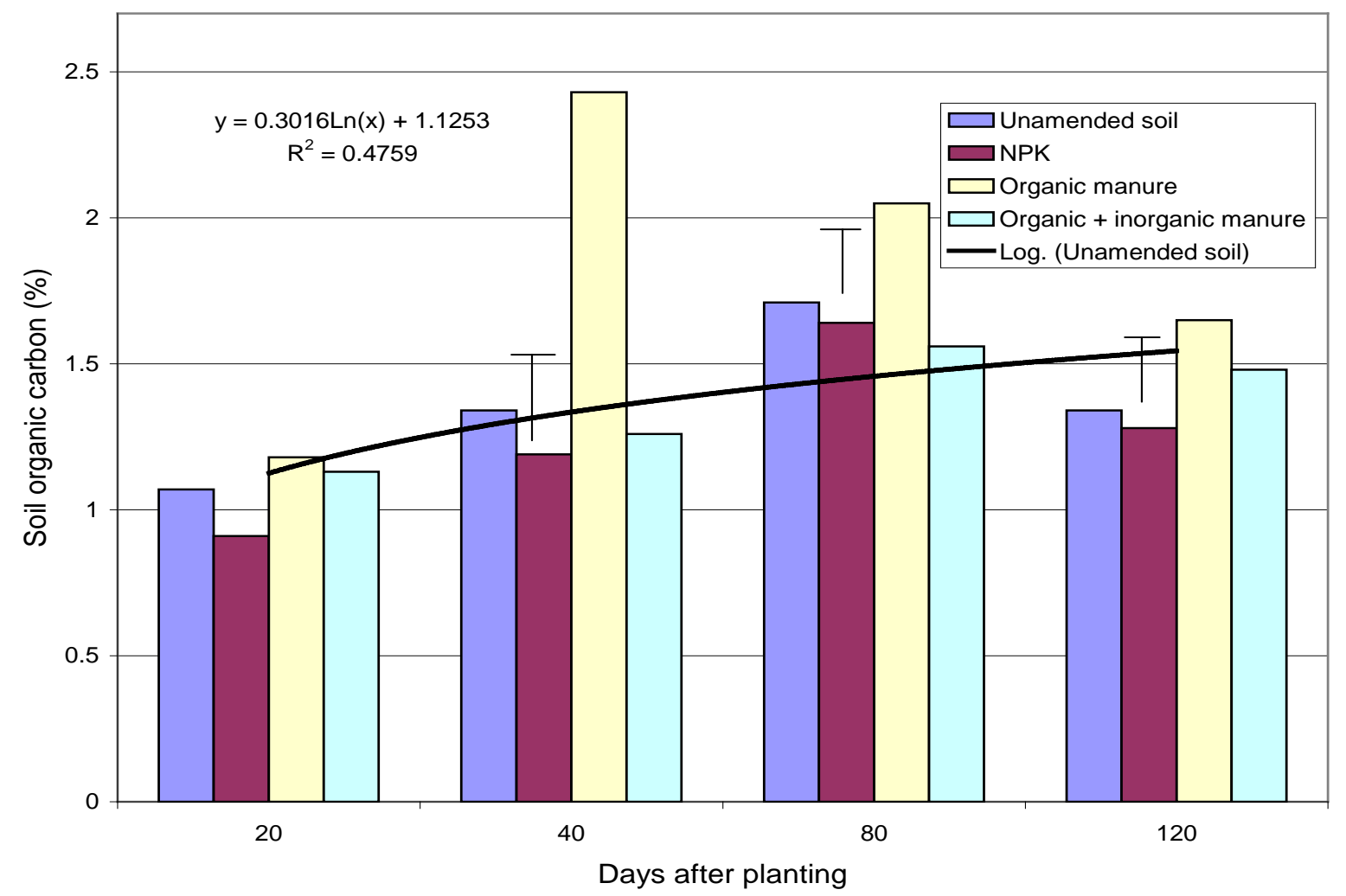

Figure 1. Time changes in soil organic carbon content. 


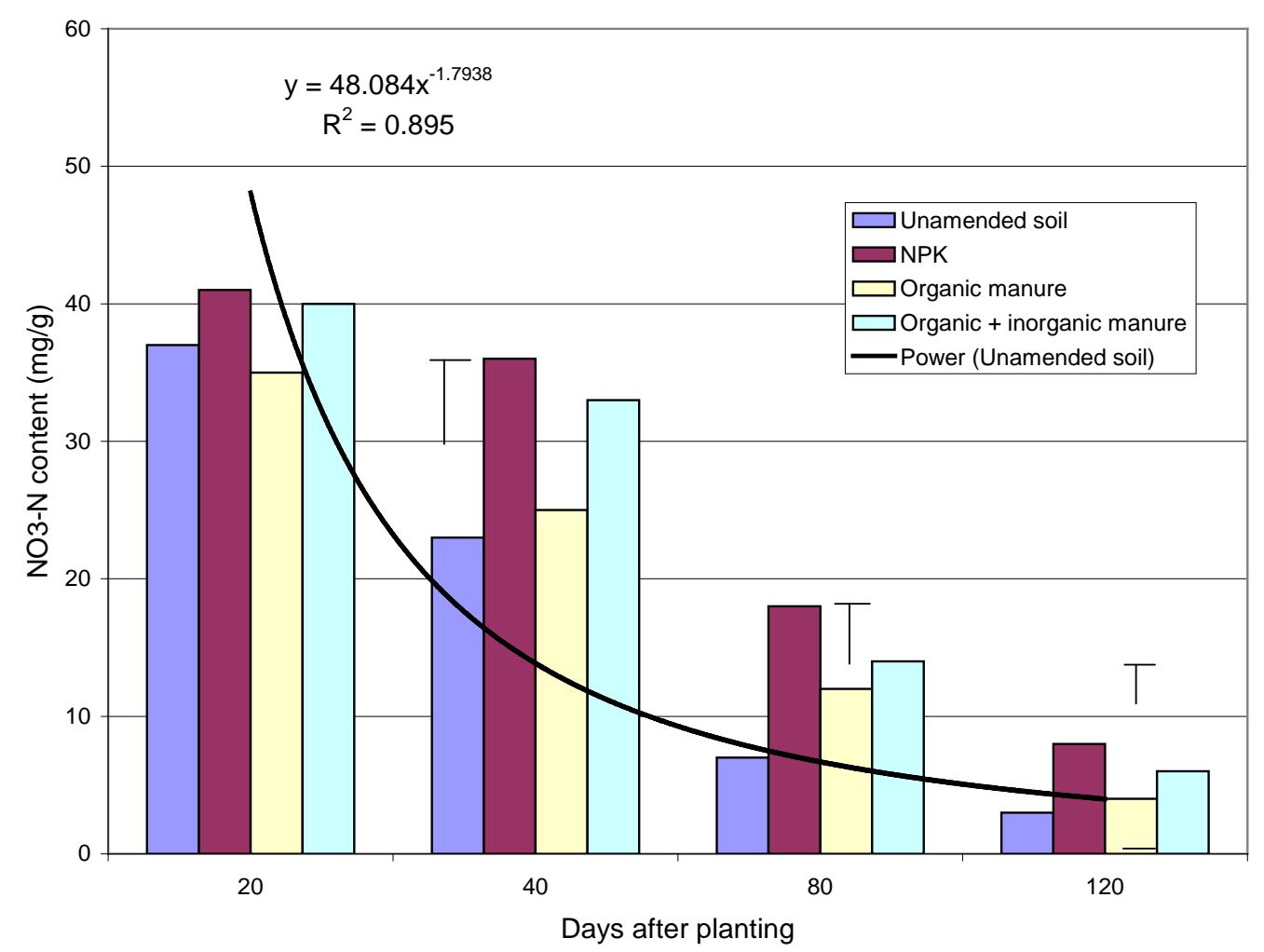

Figure 2. Time changes in available $\mathrm{N}\left(\mathrm{NO}_{3}-\mathrm{N}\right)$.

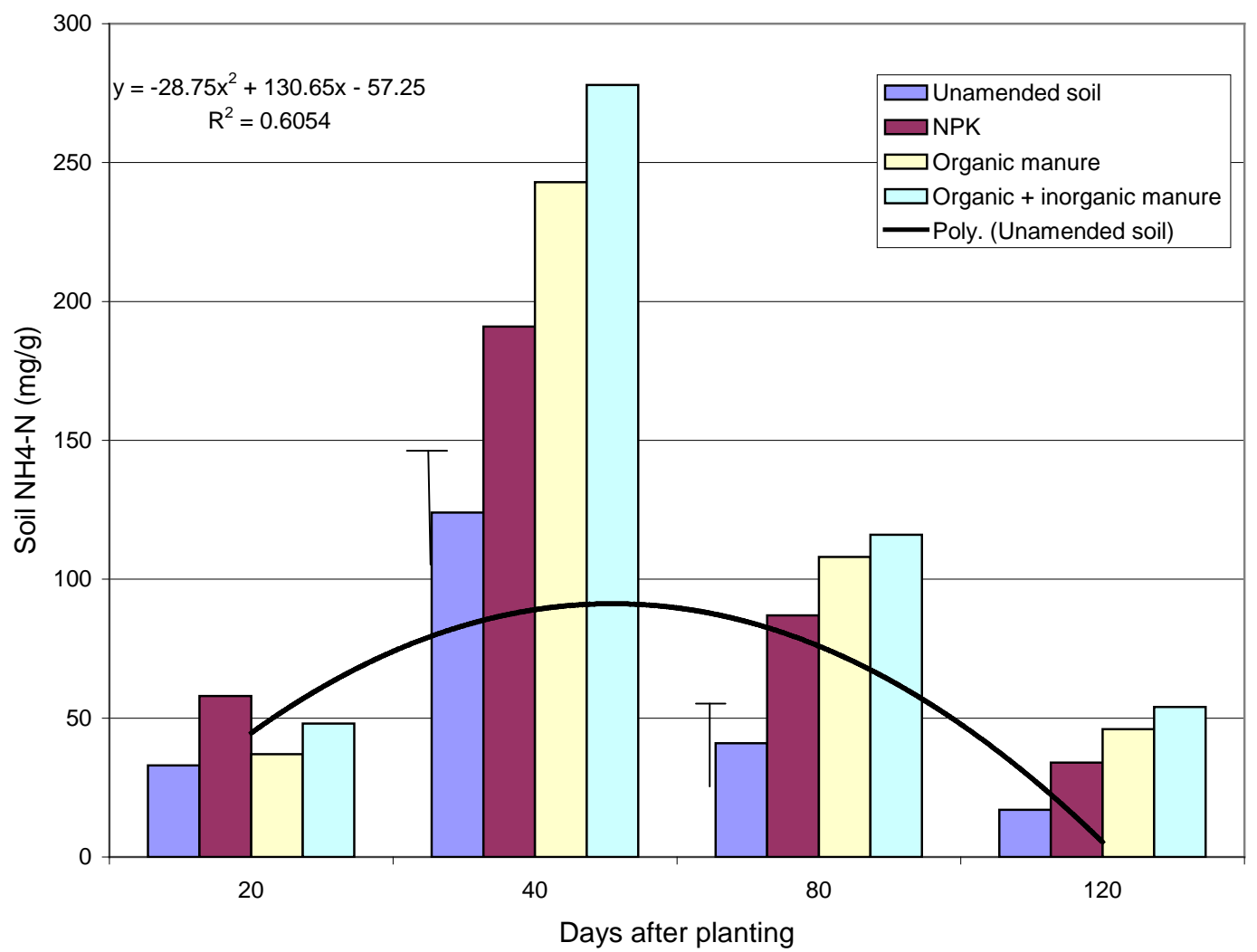

Figure 3. Time changes in soil available $\mathrm{N}\left(\mathrm{NH}_{4}-\mathrm{N}\right)$. 
Table 6. Effect of application of agricultural waste and mineral fertilizer on soil organic matter content after 3 years of continuous maize cultivation.

\begin{tabular}{cccc}
\hline Soil amendments & $\begin{array}{c}\text { Initial soil organic } \\
\text { matter (\%) }\end{array}$ & $\begin{array}{c}\text { Final soil organic } \\
\text { matter (\%) }\end{array}$ & $\begin{array}{c}\text { \% change } \\
\text { In SOM }\end{array}$ \\
\hline NPK 15:15:15 (400 kg/ha) & 1.93 & 2.43 & 0.49 \\
Chromoleana (10 t/ha) & 1.93 & 3.18 & 1.25 \\
Chromoleana (7 t/ha + 120 kg/ha NPK) & 1.93 & 3.82 & 0.99 \\
Parkia (10 t/ha) & 1.93 & 2.92 & 1.09 \\
Parkia (7 t/ha + 120 kg/ha NPK) & 1.93 & 3.02 & 0.99 \\
Neem seed cake (10 t/ha) & 1.93 & 2.92 & 1.12 \\
Neem seed (7 t/ha + 120 kg/ha NPK) & 1.93 & 2.73 & 1.22 \\
Cow dung (10 t/ha) & 1.93 & 3.05 & 2.03 \\
Cow dung (7 t/ha + 120 kg/ha NPK) & 1.93 & 3.15 & 2.08 \\
Poultry dung (10 t/ha) & 1.93 & 3.96 & 0.54 \\
Poultry dung (7 t/ha + 120 kg/ha NPK) & 1.93 & 4.01 & 0.13 \\
Melon shell (10 t/ha) & 1.93 & 2.47 & 0.08 \\
Melon shell (7 t/ha + 120 kg/ha NPK) & 1.93 & 2.06 & 0.05 \\
Unamended control & 1.93 & 2.01 & 0.13 \\
SE (27 df) & -- & 0.18 & \\
\hline
\end{tabular}

\subsection{Growth and Seed Yield of Maize}

The results of the effects of agricultural wastes and mineral fertilizer on the growth and yield characteristics of maize are shown in Table 7. Combined application of poultry manure and NPK fertilizer produced highest values of root and shoot biomass and seed yield of maize. Plot treated with poultry manure at $7 \mathrm{t} / \mathrm{ha}$ and $120 \mathrm{~kg} / \mathrm{ha}$ NPK, produced the highest value of stem girth, leaf area and plant height. The seed weight per plant, 100-seed weight, number of seeds per cob, and grain yield increased under sole application of agricultural wastes or in combination with NPK as compared with the un-amended (control) plot. The combined application of organic residues (7 t/ha) + NPK120 kg/ha produced highest seed weight per plant, 100-seed weight, and number of seeds per cob when compared with plots where sole agricultural wastes was applied.

\section{Discussion}

The results of this study confirmed that application of agricultural waste materials affected the fluxes of soil nutrients of an Ultisol of the Southern Guinea Savanna agroecological zone of Nigeria. The dynamics of microbial biomass pool (biomass $\mathrm{C}$ and $\mathrm{N}$ ) and soil organic carbon and plant available $\mathrm{N}$ differed between the unmanured and manured soil. The values of \% C mic: Corg (indicator of microbial activity in terms of the utilisation of organic carbon by the microbes and hence organic matter turnover rate) obtained could be indicative of greater access of nutrients for microbes. Although the \% C microbial to $\mathrm{C}$ organic ratio was stable for all treatments, its magnitude was not constant but increased with increases in soil C concentration. The values of \% C mic: Corg (indicator of microbial activity in terms of the utilisation of organic carbon by the microbes and hence organic matter turnover rate) obtained could be indicative of greater access of nutrients by soil microbes. $\mathrm{NH}_{4}-\mathrm{N}$ released from the decomposition of applied manure/fertilizer are substrates for soil nitrifying bacteria. Differences in amount of $\mathrm{NH}_{4}-\mathrm{N}$ in the soil may be related to differences in soil organic matter contents.

Agricultural wastes alone appeared to have negatively affected the population (and activities) of soil microbial community possibly the nitrifying bacteria and hence a possible inhibition of $\mathrm{NH}_{4}-\mathrm{N}$ nitrification. This inhibition appeared to have consequently increased the time of availability and concentrations of $\mathrm{NH}_{4}-\mathrm{N}$ in soil. The differences in the quality of the agricultural wastes measured in terms of $\mathrm{C} / \mathrm{N}$ ratios differed and could have driven the observed temporal variations in soil chemical properties (soil organic carbon, mineral $\mathrm{N}$ and microbial biomass-C and $\mathrm{N}$ ). The results of this study confirm that the organic wastes examined have markedly different decomposition patterns confirming the results of Agele et al. [12].

The temporal pattern of soil $\mathrm{NO}_{3}-\mathrm{N}$ and $\mathrm{NH}_{4}-\mathrm{N}$ release following application of agricultural wastes is pre- 
Table 7. Effect of application of agricultural waste and mineral fertilizer on yield and yield component of maize.

\begin{tabular}{|c|c|c|c|c|c|c|c|c|}
\hline \multirow{2}{*}{ Treatments } & \multicolumn{2}{|c|}{ Seed weight per plant (g) } & \multicolumn{2}{|c|}{100 seed weight (g) } & \multicolumn{2}{|c|}{ Number seed/Cob } & \multicolumn{2}{|c|}{ Seed yield(t/ha) } \\
\hline & 2008 & 2009 & 2008 & 2009 & 2008 & 2009 & 2008 & 2009 \\
\hline NPK & $778.5^{\mathrm{abc}}$ & $71.1^{\mathrm{bc}}$ & $25.91^{\mathrm{b}}$ & $21.42^{\mathrm{cd}}$ & $493^{\mathrm{bc}}$ & $456^{\mathrm{b}}$ & $4.63^{\mathrm{a}}$ & $4.19^{\mathrm{bc}}$ \\
\hline Chr & $62.4^{\mathrm{cd}}$ & $64.3^{c}$ & $25.14^{\mathrm{bc}}$ & $20.98^{\text {def }}$ & $421^{\mathrm{d}}$ & $452^{b}$ & $3.68^{\mathrm{c}}$ & $3.79^{\mathrm{de}}$ \\
\hline $\mathrm{Chr}+\mathrm{NPK}$ & $80.1^{\mathrm{ab}}$ & $70.4^{\mathrm{bc}}$ & $26.19^{\mathrm{ab}}$ & $21.10^{\text {cde }}$ & $503^{\mathrm{bc}}$ & $585^{\mathrm{a}}$ & $4.73^{\mathrm{a}}$ & $4.15^{\mathrm{ab}}$ \\
\hline $\mathrm{Nm}$ & $61.1^{\mathrm{cd}}$ & $56.7^{c}$ & $25.17^{\text {bc }}$ & $20.73^{\text {def }}$ & $401^{\mathrm{d}}$ & $356^{\mathrm{cd}}$ & $3.60^{c}$ & $3.34^{\text {de }}$ \\
\hline $\mathrm{Nm}+\mathrm{NPK}$ & $84.9^{\mathrm{ab}}$ & $68.0^{\mathrm{bc}}$ & $25.21^{\mathrm{b}}$ & $21.94^{\mathrm{bcd}}$ & $426^{\mathrm{d}}$ & $392^{\mathrm{bc}}$ & $5.01^{\mathrm{a}}$ & $4.01^{\mathrm{cd}}$ \\
\hline Pak & $54.9^{\mathrm{d}}$ & $59.4^{\mathrm{c}}$ & $24.40^{\mathrm{c}}$ & $19.40^{\mathrm{f}}$ & $398^{\mathrm{d}}$ & $331^{\mathrm{de}}$ & $3.24^{\mathrm{c}}$ & $3.50^{\mathrm{e}}$ \\
\hline $\mathrm{Pak}+\mathrm{NPK}$ & $64.3^{\mathrm{cd}}$ & $64.8^{\mathrm{c}}$ & $25.13^{\mathrm{bc}}$ & $19.36^{\mathrm{f}}$ & $417^{\mathrm{d}}$ & $386^{\mathrm{cd}}$ & $3.79^{\mathrm{b}}$ & $3.82^{\mathrm{d}}$ \\
\hline Cwd & $68.1^{\mathrm{bc}}$ & $68.3^{\mathrm{bc}}$ & $23.92^{\mathrm{bc}}$ & $21.92^{\mathrm{bcd}}$ & $378^{\mathrm{de}}$ & $392^{\mathrm{bc}}$ & $4.02^{\mathrm{b}}$ & $4.03^{\mathrm{bc}}$ \\
\hline Cwd + NPK & $80.1^{\mathrm{ab}}$ & $86.4^{\mathrm{ab}}$ & $25.13^{\mathrm{bc}}$ & $23.92^{\mathrm{a}}$ & $464^{c}$ & $571^{\mathrm{a}}$ & $4.75^{\mathrm{a}}$ & $5.10^{\mathrm{ab}}$ \\
\hline Ptr & $81.2^{\mathrm{ab}}$ & $88.7^{\mathrm{ab}}$ & $27.62^{\mathrm{a}}$ & $22.51^{\mathrm{abc}}$ & $548^{\mathrm{ab}}$ & $437^{\mathrm{b}}$ & $4.79^{\mathrm{a}}$ & $5.23^{\mathrm{a}}$ \\
\hline Ptr + NPK & $88.1^{\mathrm{a}}$ & $96.9^{\mathrm{a}}$ & $28.73^{\mathrm{a}}$ & $23.14^{\mathrm{ab}}$ & $603^{\mathrm{a}}$ & $589^{\mathrm{a}}$ & $5.20^{\mathrm{a}}$ & $5.72^{\mathrm{a}}$ \\
\hline Mel & $59.8^{d}$ & $34.9^{\mathrm{d}}$ & $24.66^{\mathrm{a}}$ & $20.33^{\mathrm{ef}}$ & $368^{\mathrm{de}}$ & $394^{\mathrm{bc}}$ & $3.53^{c}$ & $2.06^{\text {de }}$ \\
\hline $\mathrm{Mel}+\mathrm{NPK}$ & $63.4^{\mathrm{cd}}$ & $63.2^{\mathrm{c}}$ & $24.71^{c}$ & $21.94^{\mathrm{bcd}}$ & $374^{\mathrm{de}}$ & $345^{\text {cde }}$ & $3.74^{\mathrm{b}}$ & $3.73^{\text {de }}$ \\
\hline Control & $49.9^{\mathrm{d}}$ & $33.3^{\mathrm{d}}$ & $21.24^{\mathrm{d}}$ & $16.97^{\mathrm{f}}$ & $314^{e}$ & $321^{\mathrm{e}}$ & $2.94^{\mathrm{d}}$ & $1.96^{\mathrm{e}}$ \\
\hline LSD (0.05) & 18.55 & 19.42 & 2.54 & 1.44 & 66.12 & 57.11 & 0.74 & 0.62 \\
\hline
\end{tabular}

Legend: NPK: NPK fertilizer; Chr: Chromolaena; Nm: Neem; Pak: Parkia leaf; Cwd: cowdung; Ptr: Poultry manure; Mel: Melon shell; Means followed by the same letter in the same column are not significantly different at $\mathrm{P}<0.05$

sumed to have stemmed from the variable rates of decomposition of SOM. The differences in the temporal trends of plant available forms of $\mathrm{N}$ could explain the variable effects of the applied agricultural wastes in slowing down the nitification process. Increased soil retention of $\mathrm{NH}_{4}-\mathrm{N}$ due to slow rates of nitrification of applied fertilizer materials is reported [15].

The values of $\mathrm{NO}_{3}^{-} \mathrm{N}$ plus exchangeable $\mathrm{NH}_{4}{ }^{+} \mathrm{N}$ were relatively high at 30 and 60 days after planting, and this trend was consistent among the agricultural waste materials applied. The higher values were followed by consistent decline afterwards especially at the end of the experiment (120 DAP) could indicate that the manures whether applied solely or at the reduced rates combined with $120 \mathrm{~kg} / \mathrm{ha}$ mineral NPK exhibited high mineralisation rates. Among the wastes applied, poultry manure plus $120 \mathrm{~kg} / \mathrm{ha}$ NPK produced the highest values of SOC and mineral $\mathrm{N}$ while the unamended soil had the least values of these parameters. The slow nitrification process of soil applied manure and fertilizer implies increased retention period of plant available form of nitrogen $\left(\mathrm{NO}_{3}-\mathrm{N}\right.$ and $\left.\mathrm{NH}_{4}-\mathrm{N}\right)$. The $\mathrm{NO}_{3}^{-}+$exchangeable $\mathrm{NH}_{4}^{+}$(PAN) recovered from organically amended soils were higher than the unamended control. PAN was high among the agricultural waste materials applied especially for poultry manure and neem seed cake. This indicates that agricultural wastes whether applied solely or at reduced rates combined with $120 \mathrm{~kg} /$ ha mineral NPK exhibited high mineralisation rates of added organic wastes. This may have been due either to clay fixation or microbial immobilization of soil $\mathrm{N}$. Whatever the process involved, highest release of sequestered $\mathrm{N}$ occurred up to 60 days after planting (treatment application). Among the organic wastes tested, rates of $\mathrm{N}$ release (mineralization) were similar. This suggests that the forms of organic $\mathrm{N}$ contributing to the mineralizable forms of $\mathrm{N}$ among the applied organic wastes are similar.

The temporal changes in SOC contents showed declining in the status of SOC was relation to time. Positive changes obtained at 40 and 80 DAP possibly via increased rates of decomposition of added organic materials (SOM). Declines in SOC beyond 80 DAP may be associated with declining SOM pool. SOC is outstandingly higher in organically amended plots throughout the sampling period. The observed changes can also be attributed to SOM-enhanced microbial population and activities. A negative changes in soil $\mathrm{NO}_{3}-\mathrm{N}_{\text {and }} \mathrm{NH}_{4}-\mathrm{N}$ contents in the soil were observed showing decline in soil nutrient status under organic amendment alone and the control which may be attributed to faster mineralization from SOM-enhanced microbial population and activities (Figure 2 and Figure 3). The lowest values of $\mathrm{NH}_{4}-\mathrm{N}$ obtained from the applied fertilizer was observed from soil samples at 120 days after treatment application may indicate complete mineralisation of SOM of the applied organic wastes. Mineral N enhanced inhibition of nitrification has been implicated in previous study where organic wastes were used in combination with mineral $\mathrm{N}$ [15]. 
Nitrification inhibition by wastes is known, high SOM contents is reported to attenuate nitrification process [15] [16]. Agricultural wastes have the potential to inhibit urease activity and slow down the release of $\mathrm{NH}_{4}-\mathrm{N}$ into the soil (15). Also, organic matter via its sorption action is protected from rapid degradation and this slows down $\mathrm{NH}_{4}-\mathrm{N}$ release [2]. Organic (agricultural) wastes have been reported as having the ability to slow down nitrification process possibly due to their high contents of organic matter [15]. In this study, the applied agricultural) wastes appeared to have slowed down the nitrification process, and following application, the high SOM contents could have attenuated nitrification process. In addition, under the combined application of wastes and mineral NPK, agricultural wastes could have possibly reduced nitrification rate via slow hydrolysis of the mineral fertilizer (NPK).

Higher SOM contents are known to attenuate nitrification process. Organic matter, via its sorption action is protected from rapid degradation which slowed down $\mathrm{NH}_{4}-\mathrm{N}$ release. Hence the applied agricultural wastes exhibited differences in the pattern of release of inorganic $\mathrm{N}$ in particular where wastes were applied with mineral fertilizer (NPK). The possible slow nitrification of applied mineral fertilizer in treatments involving combined use of organic wastes and mineral fertilizer would have affected the release and the period of availability of $\mathrm{NH}_{4}-\mathrm{N}$ in the soil [17]. However reduction in soil $\mathrm{NO}_{2}+\mathrm{NO}_{3}-\mathrm{N}$ and $\mathrm{NH}_{4}-\mathrm{N}$ contents under sole application of wastes was obtained. Slow release of $\mathrm{NO}_{2}+\mathrm{NO}_{3}-\mathrm{N}$ and $\mathrm{NH}_{4}-\mathrm{N}$ and resultant increases in nutrient availability time in the soil for crops may imply a better synchronization of nutrients with crop demand and possibly enhancement of nutrient use efficiency of the applied manures/fertilizer. Increases in the concentrations of plant available forms of $\mathrm{N}\left(\mathrm{NO}_{2}+\mathrm{NO}_{3}-\mathrm{N}\right.$ and $\left.\mathrm{NH}_{4}-\mathrm{N}\right)$ and its period of availability in soil may possibly enhance the use efficiency of applied fertilizer and reduced rates of soil $\mathrm{N}$ losses [18]. The slow rates of the nitrification of applied fertilizer materials may imply increased retention of $\mathrm{NH}_{4}-\mathrm{N}$ and hence increases in time availability of plant available forms of $\mathrm{N}\left(\mathrm{NO}_{3}-\mathrm{N}\right.$ and $\left.\mathrm{NH}_{4}-\mathrm{N}\right)$. Rapid nutrient depletion and low fertilizer use efficiency especially in tropical agricultural systems may stem from high rates of losses of nitrogen via denitrification, volatilization and leaching [3] [19].

The forms of soil nitrogen that are readily available to plants are $\mathrm{NO}_{2}+\mathrm{NO}_{3}-\mathrm{N}$ and $\mathrm{NH}_{4}-\mathrm{N}$. $\mathrm{NO}_{3}-\mathrm{N}$ are negatively charged and are not readily adsorbed by negatively charged clay colloids and are thus susceptible to rapid losses via leaching [6]. Low rates of the nitrification and increases in time of availability of plant available forms of $\mathrm{N}\left(\mathrm{NO}_{3}-\mathrm{N}\right.$ and $\left.\mathrm{NH}_{4}-\mathrm{N}\right)$ may slow down nutrient depletion. Lengthening the period of availability of soil nutrients especially $\mathrm{N}$ may bring about a reduction in the rates of soil $\mathrm{N}$ losses. Reduction in the rates of nutrient losses/depletion and improvements in fertilizer use efficiency will promote and sustain ecosystem health. The status of soil organic matter (SOM) content after two years of cultivation irrespective of the organic wastes applied (Table 6). The carbon to nitrogen ratio is an indicator of the decomposing ability of soil organic matter and consequently of the $\mathrm{N}$ supplying potential of the soil. SOC contents (a potentially mineralisable $\mathrm{N}$ ) varied among the organic materials applied, this variation might have stemmed from the $\mathrm{C} / \mathrm{N}$ ratios of the applied organic materials. Van Kessel et al. [13] reported that the addition of organic wastes with low $\mathrm{C} / \mathrm{N}$ ratio increased inorganic $\mathrm{N}$ in soil in addition to higher microbial biomass $\mathrm{C}$. In other studies, [7] [20] obtained higher microbial $\mathrm{C}$ and $\mathrm{N}$ formation through addition of straw of high $\mathrm{C} / \mathrm{N}$ ratio. In this study, the application of plant litter/stubble increases the input of carbon into the soil. Eaton [21] reported that farming systems of the humid tropics sustain soil quality and productivity by maximizing nutrient ( $\mathrm{C}$ and $\mathrm{N}$ ) cycling, soil biota population and activities via the application or retention of plant litter/stubble.

Integrated use of agricultural wastes and NPK fertilizer improved maize grain yield as indicated by increase in seed weight per plant, 100-seed weight and the number of seed per cob. Generally, cob and seed weight per plant, 100-seed weight and number of seeds per cob were higher in organically amended plots (those treated with Chromolaena, Parkia, neem seed cake, cow dung, poultry manure and melon shell) and wastes combined with reduce level of NPK compared with the un-amended (control) plot. The combined application of agricultural wastes and NPK fertilizer improved the grain yield of maize as indicated by increase in seed weight per plant, 100-seed weight, number of seed per cob, and seed yield.

\section{Conclusion}

This study examined the effects of integrated use of some agricultural waste materials and a mineral fertilizer (commercially available compound fertilizer containing N. P. K) on the fluxes of soil nutrients on the Ultisol of the humid savanna agroecological zone of Nigeria. The treatments produced changes in SOC contents, microbial 
biomass $\mathrm{C}$ and $\mathrm{N}$, and forms of plant available $\mathrm{N}\left(\mathrm{NO}_{2}-\mathrm{N}+\mathrm{NO}_{3}-\mathrm{N}\right.$ and $\left.\mathrm{NH}_{4}-\mathrm{N}\right)$ in the soil. Higher plant available $\mathrm{N}$ was obtained from the manured compared to unmanured soils. Mineral $\mathrm{N}\left(\mathrm{NO}_{3}^{-} \mathrm{N}_{\text {plus }} \mathrm{NH}_{4}^{+} \mathrm{N}\right)$ pools and \% $\mathrm{C}$ microbial to \% C organic ratio were higher in the nutrient-rich organically amended soils. Although, organic manuring enhances short term fertility of the soil, its contribution goes beyond its role at increasing SOC build up and as nitrogen source for crop growth, it also determines the residual pool of nutrients in the soil. Differences were obtained in the pattern and amount of $\mathrm{NO}_{2}+\mathrm{NO}_{3}-\mathrm{N}$ and $\mathrm{NH}_{4}-\mathrm{N}$ released from the applied wastes. In treatments involving combined application of organic wastes and mineral fertilizer, increases in the concentrations of plant available forms of $\mathrm{N}\left(\mathrm{NO}_{2}+\mathrm{NO}_{3}-\mathrm{N}\right.$ and $\left.\mathrm{NH}_{4}-\mathrm{N}\right)$ in soil may possibly enhance the use efficiency of applied fertilizer and reduce rates of soil $\mathrm{N}$ losses. The results would advance knowledge about the chemical and biological processes of fluxes of carbon and nitrogen in the soil following organic amendment. The trends in the time dynamics of $\mathrm{C}$ and $\mathrm{N}$ in microbial biomass would help to fine tune nutrient management strategies especially for Ultisols of the humid savanna agroecology. Tropical soils under organic amendment in particular, have a wide range of mineralization potentials and this study enhances understanding of the fluxes of $\mathrm{C}$ and $\mathrm{N}$ in a tropical Ultisol. Effects of agricultural waste alone and in combination with NPK fertilizer were significant on growth and yield characters of maize. The cob weight, 100-seed weigh and seed yield per plant were higher under the sole application of agricultural wastes or in combination with NPK compared with un-amended treatment. Among the agricultural wastes tested, poultry manure increased the growth and yield characteristics of maize better than Chromolaena, Parkia, neem seed cake and melon shell.

\section{Acknowledgements}

The authors wish to gratefully acknowledge Prof. R.D. Aladesanwa for assistance in experimental design and statistical analysis of data, Messrs A. Ibitoye and A. Adeyemi for assistance in laboratory analysis of soil and plant and S.K. Adejobi for assistance in field layout, conduct of experiment and data collection. We also wish to acknowledge the anonymous reviewers.

\section{References}

[1] Nottidge, D.O., Ojeniyi, S.O. and Asawalam, D.O. (2005) Comaprative Effects of Plant Residues and NPK Fertilizer on Nutrient Status and Yield of Maize in a Humid Ultisols. Nigerian Journal of Soil Science, 15, 1-8.

[2] Odu, C.T.T. and Mba, C.C. (1991) Mineral Consideration for Maximizing Nutrient Availability through Organic Ferrtilisation. Proceeding of a National Orgainc Fertoilizer Seminar, Durbar Hotel Kaduna, 26-27 March 1991, 69-80.

[3] International Atomic Energy Agency (IAEA) (2003) Management of Crop Residues for Sustainable Crop Production, IAEA TECHDOC-1354. International Atomic Energy Agency, Vienna.

[4] Krupnik, T.J., Six, J., Ladha, J.K., Paine M.J. and van Kessel, C. (2004) An Assessment of Fertilizer Nitrogen Recovery by Grain Crops. In: Mosier, Syers, J.K. and Freney, J.R., et al., Eds., Agriculture and the Nitrogen Cycle: Assessing the Impacts of Fertilizer Use on Food Production and the Environment (SCOPE 65), Island Press, London, 193-208.

[5] Dobermann, A. and Cassmann, K.G. (2004) Environmental Dimensions of Fertilizer Nitrogen: What Can Be Done to Increase Nitrogen Use Efficiency and Ensure Global Food Security. In: Mosier, A., Syers, J.K. and Freney, J.R., et al., Eds., Agriculture and the Nitrogen Cycle: Assessing the Impacts of Fertilizer Use on Food Production and the Environment (SCOPE 65), Island Press, London, 260-278

[6] Bair, W. (1990) Characterisation of the Environment for Sustainable Agriculture in the semi-Arid Tropics. In: Singh, R.P., Ed., Sustainbale Agricutlure Issues, Perspectives and Prospects in Semi-Arid Tropics, Academic Press, Hyderabad, 90-128.

[7] Paul, G.C. and Mannan, M.A. (2006) Integrated Nutrient Management in Sugarcane to Enhance Sugar Productivity. Proceedings of International Symposium on Technologies to Improve Sugar Productivity in Developing Countries, Gullin, September 2006, 108-121.

[8] Sørensen, P. (1998) Effects of Storage Time and Straw Content of Cattle Slurry on the Mineralization of Nitrogen and Carbon in Soil. Biology and Fertility of Soils, 27, 85-91. http://dx.doi.org/10.1007/s003740050404

[9] Bechini, L. and Marino, P. (2009) Short-Term Nitrogen Fertilizing Value of Liquid Dairy Manures Is Mainly Due to Ammonium. Soil Science Society of America Journal, 73, 2159-2169. http://dx.doi.org/10.2136/sssaj2008.0217

[10] Sørensen, P. (2004) Immobilisation, Remineralisation and Residual Effects in Subsequent Crops of Dairy Cattle Slurry Nitrogen Compared to Mineral Fertiliser Nitrogen. Plant and Soil, 267, 285-296.

http://dx.doi.org/10.1007/s11104-005-0121-6 
[11] Schröder, J.J., Uenk, D. and Hilhorst, G. (2007) Long-Term Nitrogen Fertilizer Replacement Value of Cattle Manures Applied to Cut Grassland. Plant and Soil, 299, 83-99. http://dx.doi.org/10.1007/s11104-007-9365-7

[12] Agele, S.O., Adeyemo, A.J. and Famuwagun, I.B. (2011) Agricultural Wastes and Mineral Fertilizer on Soil and Plant Nutrient Status, Growth and Yield of Tomato. Archives of Agronomy \& Soil Science, 57, 91-104. http://dx.doi.org/10.1080/03650340903225040

[13] Van Kessel, J. and Reeves, J. (2002) Nitrogen Mineralization Potential of Dairy Manures and Its Relationship to Composition. Biology and Fertility of Soils, 36, 118-123. http://dx.doi.org/10.1007/s00374-002-0516-y

[14] Patra, D.D., Anwar, M., Chand, S., Kiran, U., Rajput, D.K. and Kumar, S. (2002) Nimin and Mentha spicata Oil as Nitrification Inhibitors for Optimum Yield of Japanese Mint. Communications in Soil Science and Plant Analysis, 33, 451-460. http://dx.doi.org/10.1081/CSS-120002756

[15] Ohno, T., He, Z., Taisong, I.A. and Senwo, Z.N. (2009) Influence of Tillage, Cropping, and Nitrogen Source on the Chemical Characteristics of Humic Acid, Fulvic Acid and Water-Soluble Soil Organic Matter Fractions of a Long Term Cropping System Study. Soil Science, 174, 652-660. http://dx.doi.org/10.1097/SS.0b013e3181c30808

[16] Schröder, J.J., Jansen, A.G. and Hilhorst, G.J. (2005) Long-Term Nitrogen Supply from Cattle Slurry. Soil Use and Management, 21, 196-204. http://dx.doi.org/10.1079/SUM2005306

[17] Agele, S.O., Ewulo, B.S. and Oyewusi, K. (2005) Effects of Some Soil Management Systems on Soil Physical Properties, Microbial Biomass and Nutrient Distribution under Rainfed Maize Production in a Humid Rainforest Alfisol. Nutrient Cycling in Agroecosystems, 72, 121-134. http://dx.doi.org/10.1007/s10705-004-7306-x

[18] Singh, H., Singh, S.K. and Raghubanashi, A.S. (1999) Impact of Plant Residues Quality on the Microbial Biomass Pool and Net Mineralization. Tropical Ecology, 40, 313-318.

[19] Stanford, G. and Smith, S. (1972) Nitrogen Mineralization Potential of Soils. Soil Science Society of America Journal, 36, 465-472. http://dx.doi.org/10.2136/sssaj1972.03615995003600030029x

[20] Thonnissen, C., Midmore, D.J., Ladha, J.K., Olk, D.C. and Schmidhalter, U. (2000) Leume Decomposition and Nitrogen Release When Applied as Green Manures to Tropical Vegetable Production Systems. Agronomy Journal, 92, 253260. http://dx.doi.org/10.2134/agronj2000.922253x

[21] Eaton, W.D. (2001) Microbial and Nutrient Activity in Soils from three Different Subtropical Forest Habitats in Belize, Central America before and during the Transition from Dry to Wet Season. Applied Soil Ecology, 16, 219-227 http://dx.doi.org/10.1016/S0929-1393(00)00117-7 